\title{
CCDC6/RET Fusion Protein
}

National Cancer Institute

\section{Source}

National Cancer Institute. CCDC6/RET Fusion Protein. NCI Thesaurus. Code C19945.

A fusion protein encoded by the CCDC6/RET fusion gene. This protein is comprised of the $\mathrm{N}$-terminal leucine zipper of the coiled-coil domain-containing protein 6 fused to almost the entire C-terminal cytoplasmic domain of the proto-oncogene tyrosine-protein kinase receptor Ret protein, including the tyrosine kinase domain. 